\title{
Regulation of bone cell function by acid-base balance
}

\author{
Tim Arnett \\ Department of Anatomy and Developmental Biology, University College London, Gower Street, London WC1E 6BT, UK
}

\begin{abstract}
Bone growth and turnover results from the coordinated activities of two key cell types. Bone matrix is deposited and mineralised by osteoblasts and it is resorbed by osteoclasts, multinucleate cells that excavate pits on bone surfaces. It has been known since the early 20th century that systemic acidosis causes depletion of the skeleton, an effect assumed to result from physico-chemical dissolution of bone mineral. However, our own work has shown that resorption pit formation by cultured osteoclasts was absolutely dependent on extracellular acidification; these cells are inactive at $\mathrm{pH}$ levels above about $7 \cdot 3$ and show maximum stimulation at a $\mathrm{pH}$ of about $6 \cdot 9$. Bone resorption is most sensitive to changes in $\mathrm{H}^{+}$concentration at a $\mathrm{pH}$ of about $7 \cdot 1$ (which may be close to the interstitial $\mathrm{pH}$ in bone). In this region $\mathrm{pH}$ shifts of $<0.05$ units can cause a doubling or halving of pit formation. In whole-bone cultures, chronic $\mathrm{HCO}_{3}{ }^{-}$acidosis results in similar stimulations of osteoclast-mediated $\mathrm{Ca}^{2+}$ release, with a negligible physico-chemical component. In vivo, severe systemic acidosis ( $\mathrm{pH}$ change of about -0.05 to $-0 \cdot 20$ ) often results from renal disease; milder chronic acidosis ( $\mathrm{pH}$ change of about -0.02 to -0.05 ) can be caused by excessive protein intake, acid feeding, prolonged exercise, ageing, airway diseases or the menopause. Acidosis can also occur locally as a result of inflammation, infection, wounds, tumours or diabetic ischaemia. Cell function, including that of osteoblasts, is normally impaired by acid; the unusual stimulatory effect of acid on osteoclasts may represent a primitive 'fail-safe' that evolved with terrestrial vertebrates to correct systemic acidosis by ensuring release of alkaline bone mineral when the lungs and kidneys are unable to remove sufficient $\mathrm{H}^{+}$equivalent. The present results suggest that even subtle chronic acidosis could be sufficient to cause appreciable bone loss over time.
\end{abstract}

Osteoclasts: Osteoblasts: Bone: Acid: pH

One of the fundamental problems faced by all multicellular organisms is dealing with the protons produced as a result of the metabolism of food by cells. The most basic function of the vasculature is to deliver food and $\mathrm{O}_{2}$ to cells and to remove waste, including $\mathrm{H}^{+}$and $\mathrm{CO}_{2}$, which are excreted via urine and expired air respectively. The skeletons of land vertebrates contain a massive reserve of base, which is ultimately available as a 'fail-safe' mechanism to buffer $\mathrm{H}^{+}$ if the kidneys and lungs are unable to maintain acid-base balance within narrow physiological limits.

The deleterious effects of systemic acidosis on the skeleton have long been recognised (Goto, 1918; Jaffe et al. 1932). The present review will discuss the role of acid-base balance in skeletal homeostasis in the light of more recent discoveries concerning the actions of extracellular $\mathrm{pH}$ on bone cells.

\section{Bone cell biology}

'The skeleton, out of sight and often out of mind, is a formidable mass of tissue occupying about $9 \%$ of the body by bulk and no less than $17 \%$ by weight. The stability and immutability of dry bones and their persistence over the centuries, and even millions of years after the soft tissues have turned to dust, gives us a false idea of bone during life. Its fixity after death is in sharp contrast to its ceaseless activity during life' (Cooke, 1955a,b).

Bone is a connective tissue that consists principally of a mineralised extracellular matrix plus the specialised cells, osteoblasts, osteocytes and osteoclasts. The structural component of the organic phase is type I (fibrous) collagen, which comprises about $90 \%$ of the bone protein; the inorganic phase is mainly tiny crystals of the alkaline mineral hydroxyapatite, $\mathrm{Ca}_{10}\left(\mathrm{PO}_{4}\right)_{6}(\mathrm{OH})_{2}$.

Osteoblasts, the bone-forming cells, work in groups to secrete and then mineralise patches of new bone matrix. Histologically, active osteoblasts appear as plump cuboidal cells on the bone surface (Fig. 1), with the prominent rough endoplasmic reticulum characteristic of protein-secreting cells. Active osteoblasts express large amounts of alkaline phosphatase, which probably aids mineralisation by 


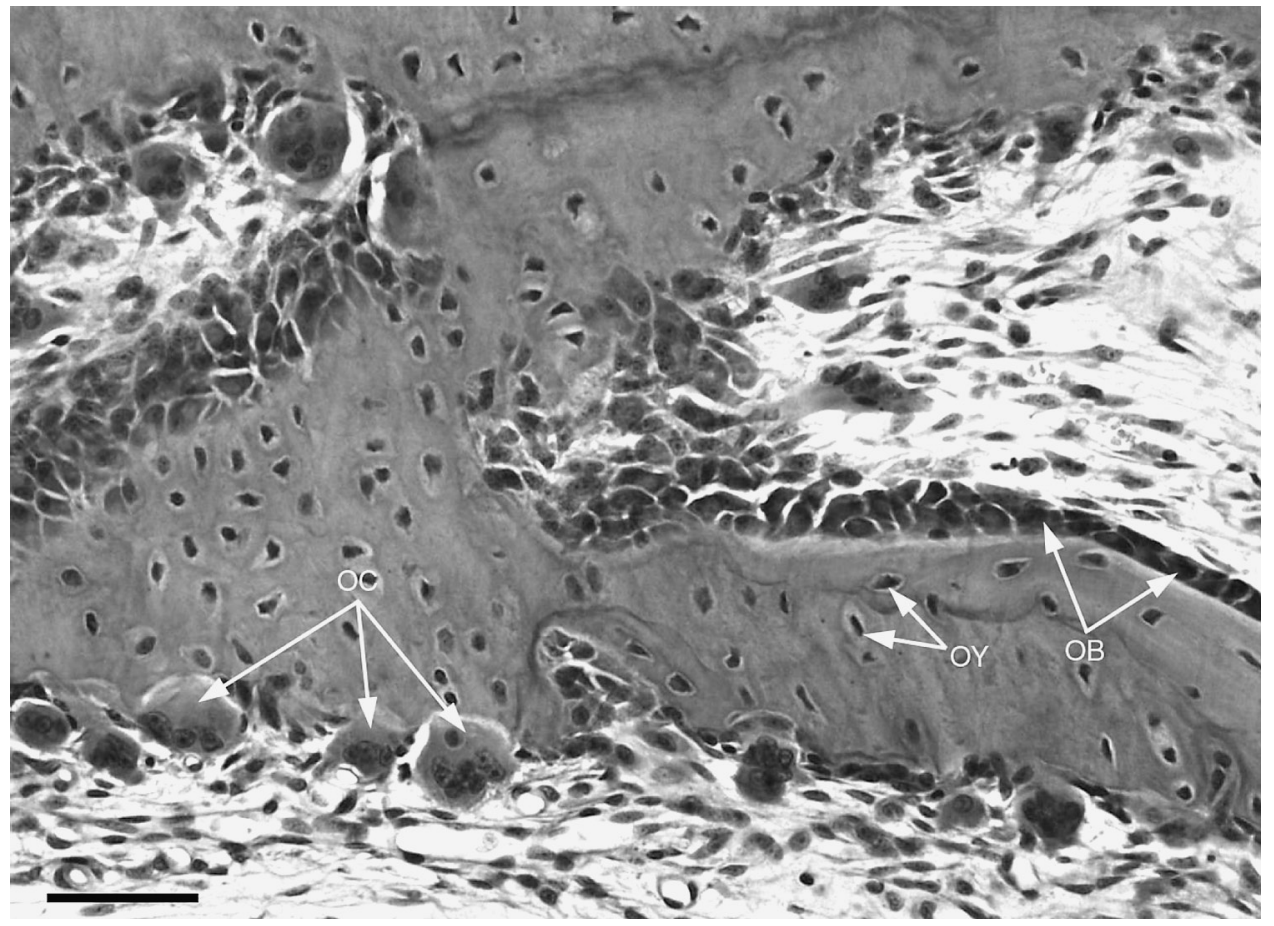

Fig. 1. Section of rapidly-remodelling bone from the jaw of a young animal, showing active osteoblasts $(\mathrm{OB})$ forming bone; osteocytes (OY) entombed in bone matrix; multinucleate osteoclasts (OC) forming resorption pits in the bone surface. Numerous fibroblast-like cells and capillaries are evident in the surrounding stroma. Scale bar $50 \mu \mathrm{m}$.

liberating inorganic phosphate. Quiescent bone surfaces are covered by a near-continuous single layer of flattened inactive osteoblasts, often referred to as 'bone-lining cells'. Osteoblasts are derived from mesenchymal progenitor cells that in the bone marrow, at least, are also capable of differentiating into adipocytes and fibroblasts. Osteoblasts, or their progenitors, express receptors for many hormones, including those for parathyroid hormone, 1,25-dihydroxycholecalciferol, sex steroids and corticosteroids; they are also responsive to, and may produce, a wide range of growth factors and cytokines. During bone formation some osteoblasts become engulfed by the accumulating matrix around them and differentiate into osteocytes, the interconnected low-density network of cells that ramify throughout all living bone (Fig. 1). Osteocytes are thought to mediate the remarkable mechanical responsiveness of bone by functioning as strain sensors that communicate with cells (osteoblasts and osteoclasts) on bone surfaces.

The destruction of bone is accomplished by osteoclasts, large motile multinucleate cells of promonocytic origin that resorb characteristic 'scalloped' pits and trails in bone surfaces (Fig. 1). Osteoclasts are formed by the fusion of mononuclear promonocytic precursors present in the marrow and circulation. They form resorption pits by attaching tightly to the bone surface, secreting protons to dissolve the mineral phase, and proteolytic enzymes (chiefly cathepsin K) to degrade the collagenous matrix. Osteoclasts achieve a high surface area of interaction with the bone by means of a convoluted membranous organ, the so-called 'ruffled border'; the adjacent resorption space can be considered as a specialised extracellular lysosome. Osteoclasts express high levels of tartrate-resistant acid phosphatase, the function of which is uncertain. Mature osteoclasts express receptors for calcitonin, a potent inhibitory hormone, and for prostaglandins, but appear not to be directly responsive to most other hormones or growth factors.

During adult life the skeleton undergoes a continual process of repair and renewal. Bone remodelling is a surface phenomenon; the turnover rate in trabecular bone may be up to ten times greater than that in cortical bone, reflecting the large surface area presented by the former tissue. Mineralised bone matrix is resorbed by osteoclasts and replaced in plywood-like layers, or lamellae, by groups of osteoblasts. This sequence of events is tightly coordinated both temporally and spatially. Under normal circumstances in young adults remodelling activity keeps overall bone mass relatively constant. However, ageing, the menopause and many other pathophysiological states can alter the balance of the turnover process, such that resorption begins to outstrip formation, leading to net bone loss and ultimately osteoporosis. This outcome could be the result not only of enhanced osteoclastic resorption but also of reduced osteoblastic function. Trabecular bone sites, for example, in the vertebral bodies (see Fig. 2) or in the ends of the long bones are particularly susceptible to remodelling imbalances, as a result of the relatively high turnover rate (about $25 \%$ per year).

\section{Acid-base balance}

Because the machinery of cells is very sensitive to changes in $\mathrm{H}^{+}$concentration, precise maintenance of $\mathrm{pH}$ in the blood 

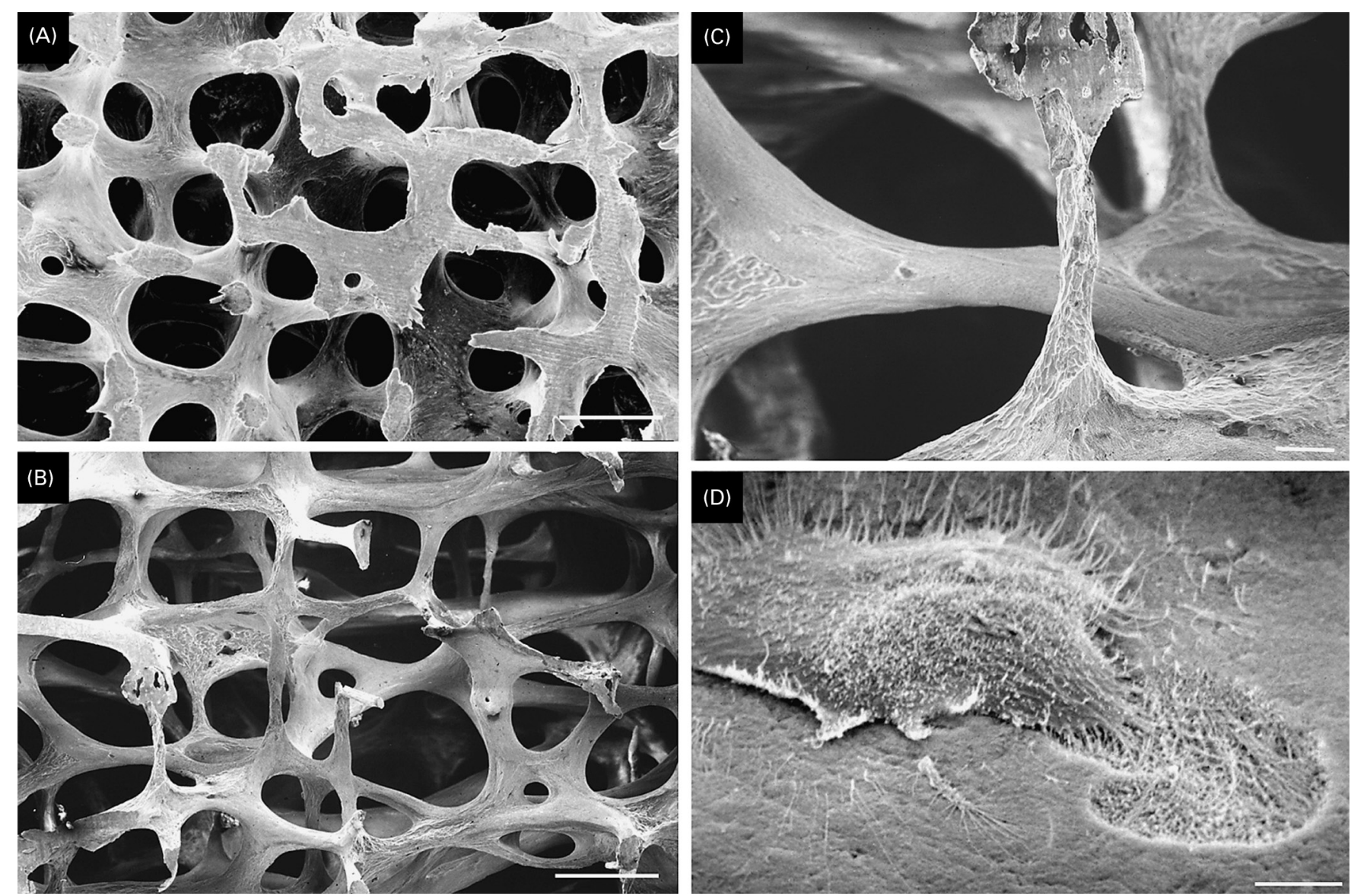

Fig. 2. (A, B), Scanning electron micrographs of vertical sections through the bodies of the third lumbar vertebrae (after removal of bone cells and soft tissues) of a normal 30-year-old woman and a 71-year-old woman, respectively. For the older woman severe osteoporotic changes are evident; the trabeculae are eroded to thin mechanically-insufficient rods. Scale bars $500 \mu \mathrm{m}$. (C), High power detail of micrograph B, showing extensive osteoclastic resorption pits on the vertical trabecular element in the foreground; this element displays a possible microfracture callus at the top. Scale bar $100 \mu \mathrm{m}$. (D), Scanning electron micrograph of an acid-activated rat osteoclast, with adjacent resorption pit, cultured on a slice of polished cow bone. Scale bar $10 \mu \mathrm{m}$.

and extracellular fluid is needed. Blood $\mathrm{pH}$ is buffered by plasma proteins, by the numerous histidine residues of haemoglobin and, most importantly, via the $\mathrm{CO}_{2}-\mathrm{HCO}_{3}{ }^{-}$ system. Addition of $\mathrm{H}^{+}$to the system will result in a $\mathrm{pH}$ decrease with a reduction of $\mathrm{HCO}_{3}{ }^{-}$levels without substantial alteration of the $\mathrm{CO}_{2}$ concentration; this process is termed a 'metabolic acidosis'. $\mathrm{H}^{+}$generated in this way, together with associated waste anions, must be excreted via the kidneys to produce acidified urine. In renal disease, which is the major cause of chronic severe systemic acidosis, the ability of the kidneys to secrete $\mathrm{H}^{+}$into the urine (and to reabsorb $\mathrm{HCO}_{3}^{-}$) is impaired or lost; arterial blood $\mathrm{pH}$ in severe renal metabolic acidosis may be as low as about 7-2. Conversely, addition of $\mathrm{CO}_{2}$ to the system as a result of respiration causes an increase in $\mathrm{H}^{+}$concentration (i.e. $\mathrm{pH}$ reduction) without marked alteration of the $\mathrm{HCO}_{3}{ }^{-}$ concentration. Normally, $\mathrm{CO}_{2}$ is expelled via the lungs, but when this process does not occur to the necessary extent, usually because of chronic respiratory diseases or, acutely, due to severe exercise, a 'respiratory acidosis' results.

Systemic acidosis, albeit of a generally mild nature, may thus result from high-protein diets, ingestion of inorganic acids or their equivalents or simply as a result of declining renal, respiratory and vascular function with advancing age. Acidosis can also arise locally (i.e. at tissue level) as a result of reduced vascular supply due to inflammations, infections, tumours, wounds, diabetes or ageing. At the cellular level, a basic action of many growth factors and cytokines is to stimulate rapid $\mathrm{H}^{+}$efflux from cells, most simply as a result of increased cellular metabolism; the mitogens parathyroid hormone and insulin-like growth factor 1 exert similar effects on cultured osteoblasts (Barrett et al. 1997; Santhanagopal \& Dixon, 1999) or whole bone (Belinsky \& Tashjian, 2000).

Although the $\mathrm{pH}$ of arterial blood is normally about $7 \cdot 40$, and that of venous blood about $7 \cdot 36$, it is important to bear in mind that the $\mathrm{pH}$ of the extracellular fluid bathing cells is likely to be $<7.36$ and subject to complex dynamic gradients, depending on the metabolic activity of the cells and their distance from the nearest capillary. In view of the obvious technical difficulties, this area has not been well investigated. Data are not available for bone, but in normal skin interstitial $\mathrm{pH}$ has been measured at about 7.1 (Martin \& Jain, 1994). 


\section{Action of acidosis on bone in vivo}

It was noted $>80$ years ago that acid feeding in rabbits resulted in skeletal depletion (Goto, 1918). Following the suggestion of Albright \& Reifenstein (1948), $\mathrm{Ca}^{2+}$ balance studies provided evidence that the skeleton could play a homeostatic role in buffering acid loads (Lemann et al. 1966; Relman, 1968). Systemic acidosis probably contributes directly to renal osteodystrophy, including the osteomalacic component of this disease (Avioli, 1978; Cunningham et al. 1982). However, the contribution made by acidosis to bone loss in chronic human kidney disease has been difficult to evaluate in most studies because of the resulting perturbations in the 1,25-dihydroxycholecalciferol-parathyroid hormone axis.

Studies of experimental acidosis in rats (achieved by feeding $\mathrm{NH}_{4} \mathrm{Cl}$, which leaves a residue of $\mathrm{HCl}$ after metabolism and excretion of the nitrogenous component) indicated that osteoclastic bone resorption was increased, causing osteoporosis (Barzel \& Jowsey, 1969; Chan et al. 1985). Moreover, in thyroparathyroidectomised rats, acute $\mathrm{NH}_{4} \mathrm{Cl}$-induced $\mathrm{HCO}_{3}{ }^{-}$acidosis was shown to result in a striking hypercalcaemia that was prevented by calcitonin or colchicine, implying osteoclast involvement (Kraut et al. 1984; see also Arnett \& Dempster, 1990). However, despite these findings, and the results summarised later, the assumption has persisted that bone would buffer an acid load primarily via physico-chemical release of alkaline bone mineral, and that the skeleton thus acts as a 'giant ionexchange column' (Green \& Kleeman, 1991; Barzel, 1995).

\section{Effects of pH on bone cells}

\section{Osteoclasts}

The direct effects of $\mathrm{pH}$ on bone resorption were discovered when it was found that raising ambient $\mathrm{CO}_{2}$ levels caused osteoclasts, isolated from fragmented rat bones and then cultured on polished cow bone slices, to excavate character- istic resorption pits. To investigate whether this effect was due to changes in $\mathrm{H}^{+}$concentration, osteoclasts were cultured overnight in low- $\mathrm{HCO}_{3}{ }^{-}$media without $\mathrm{CO}_{2}$, using an artificial buffering system to maintain a range of $\mathrm{pH}$ values between 6.8 and 7.4. Osteoclasts were observed to be almost inactive at $\mathrm{pH} 7.4$, which corresponds to "physiological' or blood $\mathrm{pH}$, but resorption pit formation increased steeply as pH was reduced (Arnett \& Dempster, 1986, 1987). Surprisingly, osteoclasts resorb bone efficiently even at $\mathrm{pH}$ 6.3-6.4, although their survival may be somewhat reduced (Murrills et al. 1993). Subsequent short-term experiments using physiological $\mathrm{CO}_{2}-\mathrm{HCO}_{3}{ }^{-}$buffering indicated that osteoclasts are particularly sensitive to $\mathrm{pH}$ changes at approximately $\mathrm{pH} 7 \cdot 1$, such that $\mathrm{pH}$ reductions of only a few hundredths of a unit caused a doubling of resorption pit formation; below a $\mathrm{pH}$ of about 7.0, the stimulatory effect begins to plateau (Arnett \& Spowage, 1996). Whether the extracellular $\mathrm{pH}$ adjacent to osteoclasts in bone is approximately $7 \cdot 1$, as is the case for skin (Martin \& Jain, 1994), remains to be determined. This acid-activation response has been observed in all species studied to date (Figs. 3-5). Importantly, this is not a short-term effect from which tachyphyllaxis (or 'escape') occurs, as is often the case for hormone-mediated phenomena. Longer-term cultures show that acid-activated osteoclasts continue to form resorption pits over periods of $\geq 7 \mathrm{~d}$, magnifying the effects of modest $\mathrm{pH}$ differences (Fig. 6).

Further studies have shown that osteoclast activation can be considered as a two-step process. The initial 'switching on' of resorption requires acidification of the extracellular environment of the osteoclast to $\mathrm{pH}<7 \cdot 2$; further stimulation by other factors can then occur (for example, see Fig. 7). Clearly, a very wide range of hormones, cytokines, growth factors and other agents are known to exert a stimulatory action on bone resorption. Some agents such as parathyroid hormone, 1,25-dihydroxycholecalciferol, prostaglandins and interleukin 1 have long been recognised,
(A)

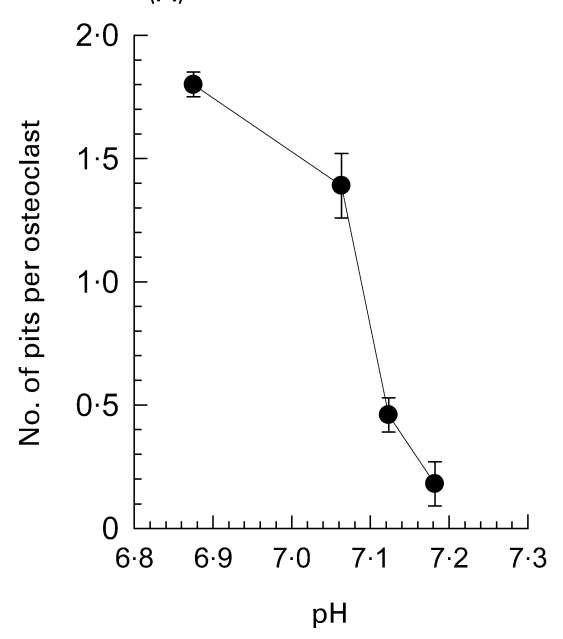

(B)

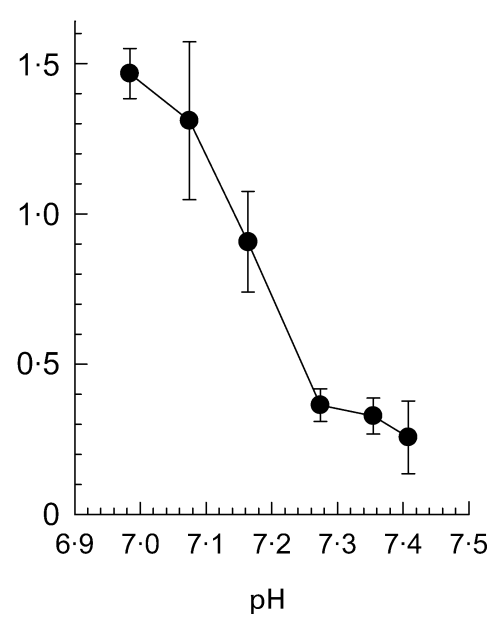

(C)

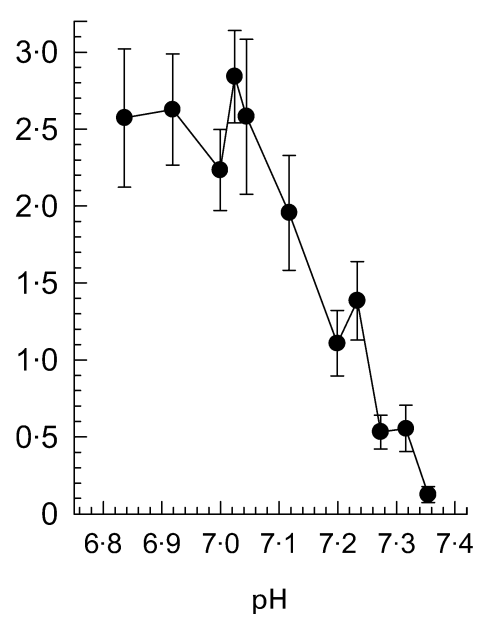

Fig. 3. Acid activation of resorption pit formation by rat (A), chick (B), and human osteoclastoma-derived osteoclasts (C) cultured $24 \mathrm{~h}$ on polished ivory discs (-) Culture medium was buffered by $\mathrm{CO}_{2} / \mathrm{HCO}_{3}^{-}$and $\mathrm{pH}$ was adjusted by addition of $\mathrm{HCl}$ or $\mathrm{NaOH}$; $\mathrm{pH}$ measurements were made by blood gas analysers. Values are means with their standard errors represented by vertical bars for five determinations. 


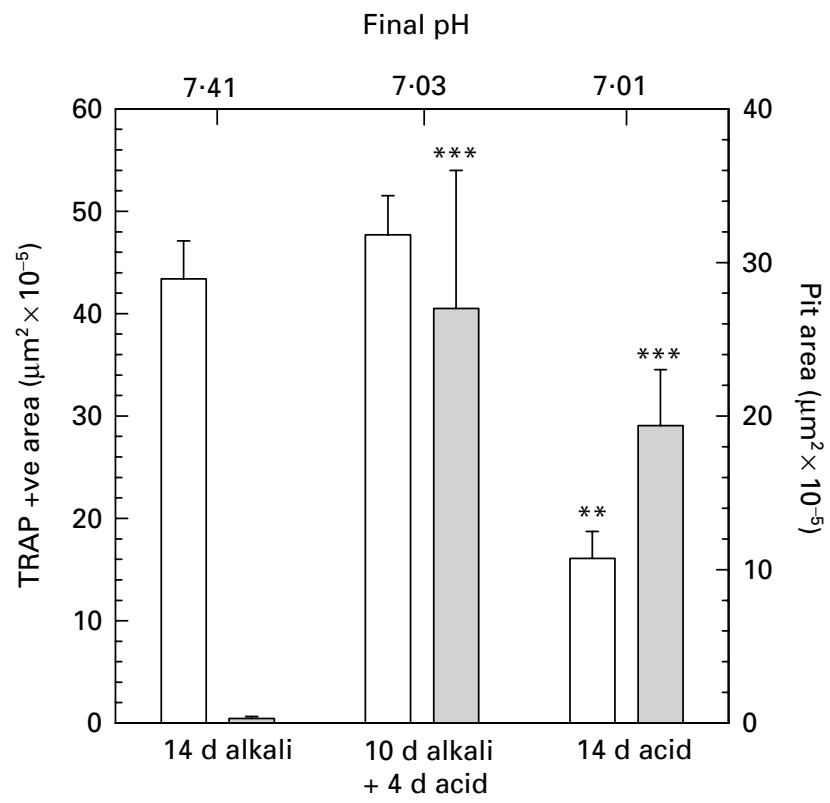

Fig. 4. Effects of $\mathrm{pH}$ variations on osteoclast formation $(\square)$ and resorption $(\square)$ in mouse marrow cultures. Incubation of mouse marrow cultures in control medium at blood $\mathrm{pH}(7 \cdot 41)$ for $14 \mathrm{~d}$ resulted in abundant tartrate-resistant acid phosphatase-positive (TRAP + ve) multinucleated osteoclast formation, but almost no resorption. In cultures maintained in alkaline medium for $10 \mathrm{~d}$, followed by $4 \mathrm{~d}$ in acidified medium, formation of TRAP-positive osteoclasts was similar to that at $14 \mathrm{~d}$ at $\mathrm{pH} 7.41$ but resorption pit formation was increased 93-fold. Continuous incubation in acidified media ( $\mathrm{pH}$ 7.01) for $14 \mathrm{~d}$ reduced TRAP-positive multinucleate cell formation, but further increased the pit area:TRAP-positive area. Values are means with their standard errors represented by vertical bars. Significantly different from the $14 \mathrm{~d}$ alkaline medium values: ${ }^{\star \star} P<0.01,{ }^{* \star *} P<0.001$. (Reproduced by courtesy of Dr M. Morrison.)

based on investigations both in vivo and in vitro; other agents such as receptor activator of nuclear factor kappa B ligand (RANKL also termed osteoprotegerin ligand; Lacey et al. 1998) and purine nucleotides (Morrison et al. 1998; Hoebertz et al. 2001) were discovered more recently. However, the critical interaction of osteolytic agents with $\mathrm{pH}$ (illustrated in Figs. 7 and 8) has not always been appreciated.

In contrast, the formation of osteoclasts from marrow precursors is not stimulated by reduced extracellular $\mathrm{pH}$, and may even show slight inhibition (Morrison \& Arnett, 1998). However, osteoclasts formed in long-term mouse marrow cultures at blood $\mathrm{pH}(7 \cdot 4)$ show no resorptive activity until stimulated by acidification (Fig. 4).

\section{Osteoblasts}

Studies by Bushinsky and colleagues (Bushinsky, 1995; Frick \& Bushinsky, 1998) have shown that the negative impact of acidification on bone may not be confined to proresorptive effects. Cultured osteoblasts show reduced collagen synthesis and mineralisation when $\mathrm{pH}$ is reduced. Our own observations indicate that the formation of mineralised bone nodules in long-term osteoblast cultures is completely blocked by acidification to $\mathrm{pH} 6.9$ (Fig. 9).

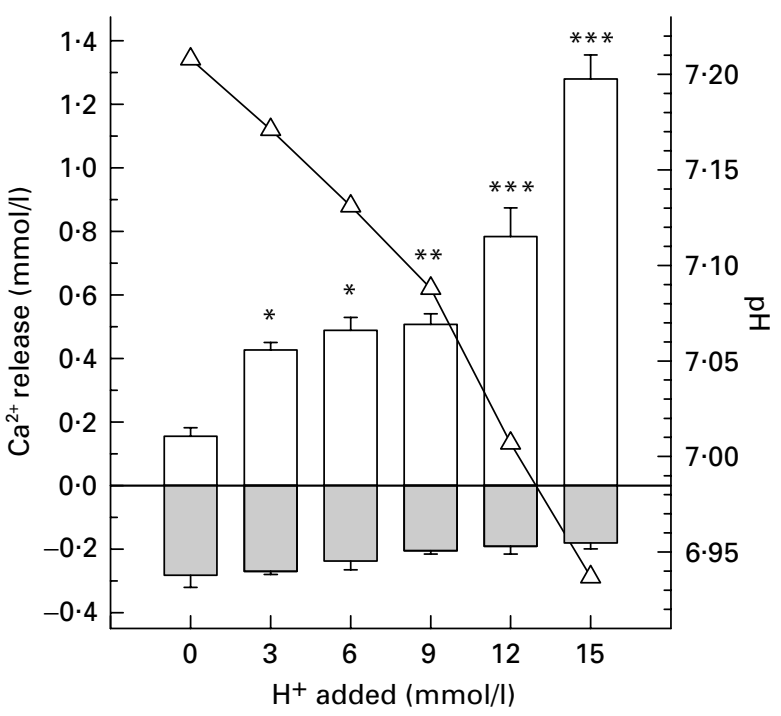

Fig. 5. Stimulatory effect of small decreases in medium $\mathrm{pH}(\triangle-\triangle)$, achieved by adding hydrogen ions (i.e. $\mathrm{HCO}_{3}{ }^{-}$acidosis) as hydrochloric acid, on calcium ion release from live mouse half-calvaria cultured for $3 \mathrm{~d}(\square)$. In dead bones, killed by freeze thawing $(\square)$, a net calcium ion influx occurred which was slightly reduced as $\mathrm{pH}$ decreased. Values are means with their standard errors represented by vertical bars for five determinations. Significantly different from the non-acidified control values: ${ }^{\star} P<0.05,{ }^{*} P<0.01,{ }^{* * *} P<0.001$.

\section{Whole bone}

The previously mentioned cell-culture studies demonstrated conclusively that acidosis stimulates osteoclasts to form three-dimensional resorption pits on mineralised tissue surfaces, a process that involves removal of both mineral and collagenous organic matrix. Whole-bone organ-culture experiments have been used to address the question of whether chronic acidosis stimulates $\mathrm{Ca}^{2+}$ efflux and bone depletion in vivo by physico-chemical or cell-mediated means. The work of Bushinsky and colleagues (Bushinsky et al. 1983, 1985; Bushinsky \& Lechleider, 1987) using cultured mouse calvarial bones indicated that during the first few hours of exposure to acidosis there was a physicochemical release of $\mathrm{Ca}^{2+}$ from bone coupled to a large net influx of $\mathrm{H}^{+}$into bone. After $2 \mathrm{~d}$ exposure to acidosis a cell-mediated component of $\mathrm{Ca}^{2+}$ release from calvaria was also detected (Bushinsky, 1989, 1995). Other studies from the same group reported that $\mathrm{HCO}_{3}{ }^{-}$acidosis was a more effective stimulator of $\mathrm{Ca}^{2+}$ release from bone than $\mathrm{CO}_{2}$ acidosis (Bushinsky, 1989, 1995; Bushinsky et al. 1992). Work from another group (Goldhaber \& Rabadjija, 1987; Rabadjija et al. 1990) indicated that $\mathrm{Ca}^{2+}$ efflux from calvarial bones subjected to $\mathrm{HCO}_{3}{ }^{-}$acidosis was almost entirely dependent on osteoclastic resorption, since the effect was completely blocked by calcitonin, the specific inhibitory hormone for osteoclasts. Our own experiments (Figs. 5 and 10) confirmed this finding and showed that $\mathrm{HCO}_{3}^{-}$acidosis stimulates resorption of cultured mouse calvarial bones in a similar manner to that observed for mature osteoclast cultures (Meghii et al. 2001); the sensitivity of these bones is 

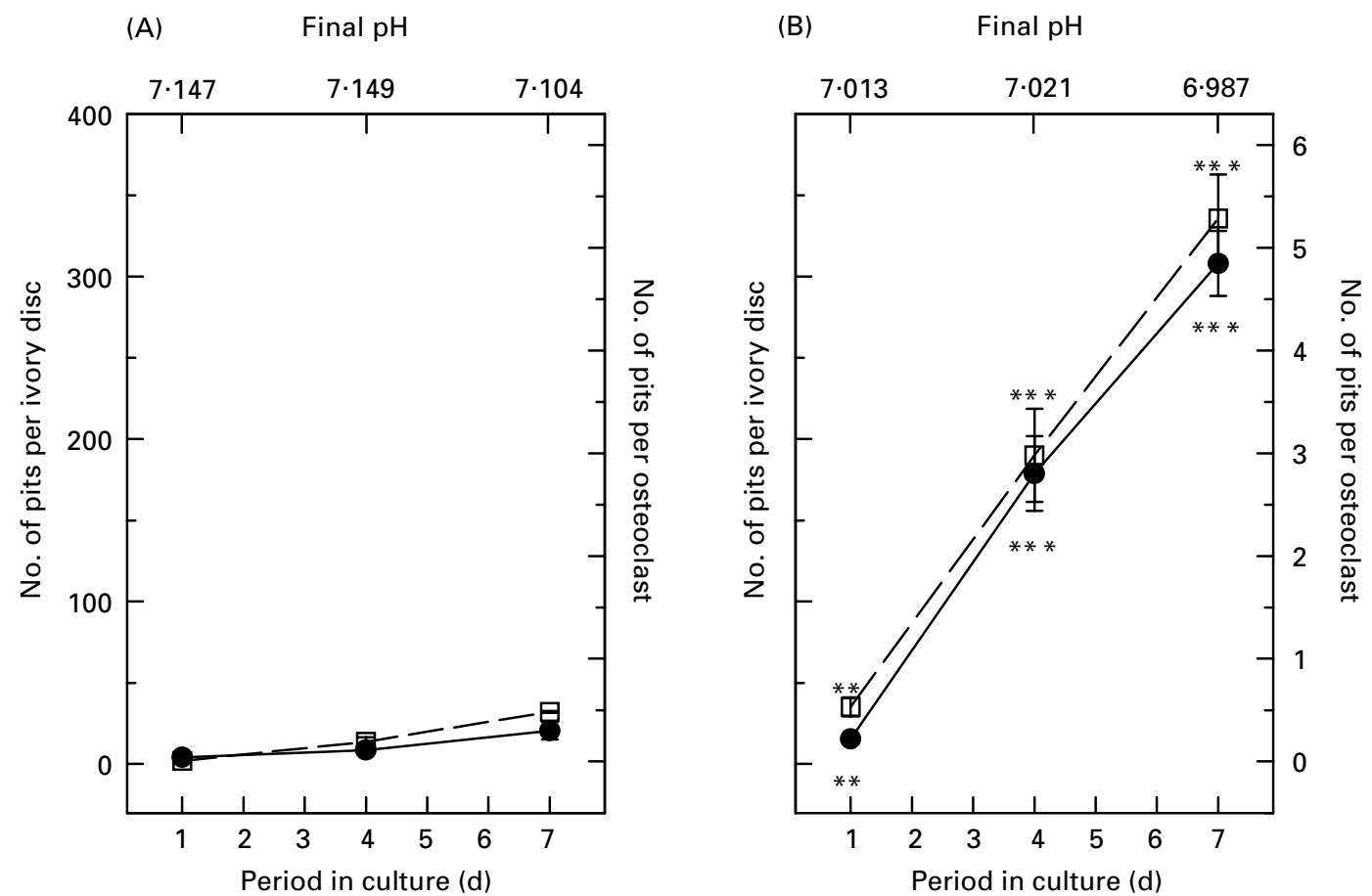

Fig. 6. Long-term stimulation of resorption pit formation by mature rat osteoclasts cultured on ivory discs in a slightly-acidified medium (medium $+6.5 \mathrm{mmol} \mathrm{H}^{+}$; B) for up to $7 \mathrm{~d}$. A 15-fold increase in resorption is associated with a mean pH difference of only 0.13 unit. (--), pits per ivory disc; ( $\square-\square-\square$ ), pits per osteoclast. Values are means with their standard errors represented by vertical bars for five determinations. Significantly different from the respective values for the non-acidified control $(\mathrm{A}):{ }^{* *} P<0 \cdot 01,{ }^{* * *} P<0.001$.

such that a $\mathrm{pH}$ reduction of about $0 \cdot 25$ units is sufficient to cause a 9-fold increase in osteoclast-mediated $\mathrm{Ca}^{2+}$ release (Fig. 5). It was also found that the established osteolytic actions of agents such as parathyroid hormone, 1,25-dihydroxycholecalciferol and prostaglandin $\mathrm{E}_{2}$ were themselves dependent on acidification (Fig. 8).

\section{Mechanism of action of pH effects on bone cells}

Several possibilities exist for the mechanism by which extracellular acidification activates and stimulates osteoclasts to resorb bone. Obviously, a low ambient $\mathrm{pH}$ will favour resorption simply by reducing the gradient against which osteoclasts must pump $\mathrm{H}^{+}$across the ruffled border. However, given the steepness of the response of the osteoclasts to small changes in extracellular $\mathrm{pH}$, this factor seems unlikely to account for the entire effect. Thus, it is not unreasonable to imagine that a $\mathrm{pH}$ 'receptor' coupled to some signalling-amplification system could be present on or in the osteoclast. It is possible that a $\mathrm{pH}$ 'receptor' on the osteoclast cell membrane could be of the acid-sensing ion channel type described by Waldmann et al. (1999).

Although the mechanism by which osteoclasts detect $\mathrm{pH}$ changes is still unknown, progress has been made in understanding the 'downstream' responses of the key resorptive enzymes to extracellular acidification. Acidosis in vitro induces the activity of the vacuolar-type $\mathrm{H}^{+}$-ATPase in osteoclast membranes within minutes (Nordström et al. 1997); this enzyme is thought to be primarily responsible for pumping $\mathrm{H}^{+}$out of the osteoclast into the extracellular resorption compartment in order to dissolve hydroxyapatite. Recent work has demonstrated that upregulation of osteoclastic expression of mRNA for carbonic anhydrase II and for the calcitonin receptor occurs within $4 \mathrm{~h}$ after acidification (Biskobing \& Fan, 2000). Carbonic anhydrase II is thought to play an important role in the intracellular generation of $\mathrm{H}^{+}$for resorption, and the calcitonin receptor is a marker for terminal differentiation of the osteoclast phenotype. Our own recent findings (A Brandao-Burch, $\mathrm{S}$ Meghji and $\mathrm{T}$ Arnett, unpublished results) show that bone organ cultures maintained at $\mathrm{pH} 7 \cdot 0$ exhibit striking up regulation of mRNA for tartrate-resistant acid phosphatase and cathepsin K (Fig. 11).

\section{Dietary considerations}

Metabolic oxidation of proteins containing $\mathrm{S}$ and $\mathrm{P}$ ultimately yields $\mathrm{H}^{+}$residues corresponding to $\mathrm{H}_{2} \mathrm{SO}_{4}$ and $\mathrm{H}_{3} \mathrm{PO}_{4}$, which must be excreted via the kidneys. The average US diet has been estimated to generate an inorganic $\mathrm{H}^{+}$residue of about $0 \cdot 1 \mathrm{~mol} / \mathrm{d}$ (Barzel, 1995), which is, for example, equivalent to approximately $8 \mathrm{ml}$ concentrated $\mathrm{HCl}$. Although high protein intake (particularly of animal protein) has often been regarded as a risk factor for low bone mass, strong data also exist (e.g. from the Framingham Study) for the opposite effect. It should also be borne in mind that vegetable proteins may deliver equivalent amounts of S (see Heaney, 2001). Green vegetables of the cabbage family also contain appreciable quantities of S. There is reasonable evidence that increasing 


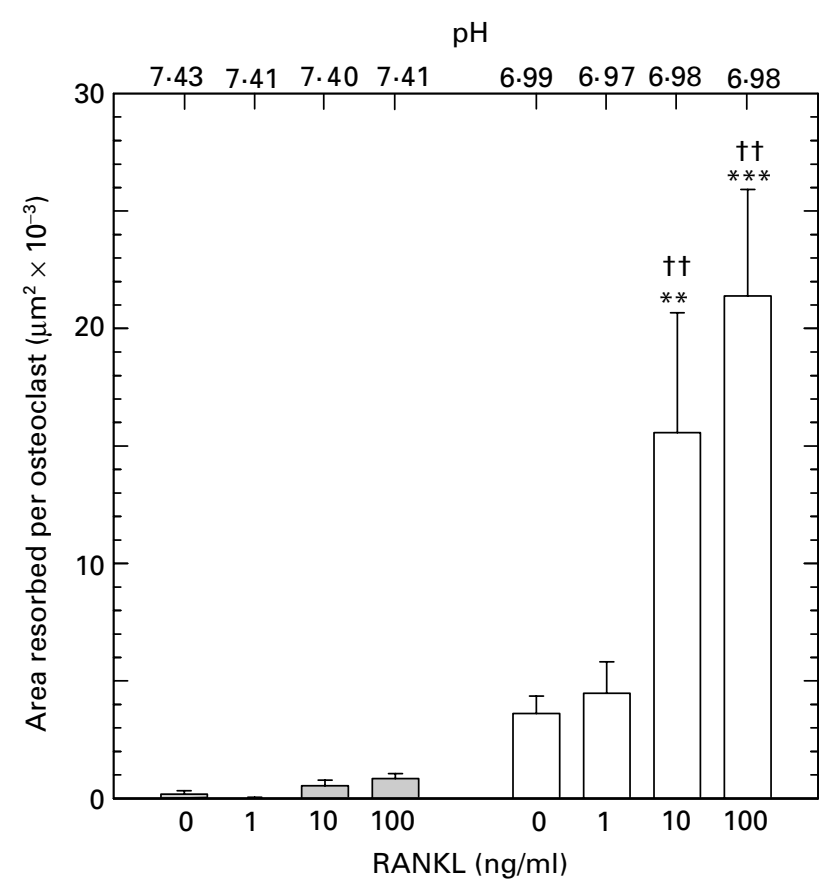

Fig. 7. Synergistic stimulatory effects of low $\mathrm{pH}$ and receptor activator of nuclear factor kappa B ligand (RANKL) on osteoclastic resorption. At physiological (blood) $\mathrm{pH}$ of approximately 7.4 ( $\square$ ) basal resorption was very low and RANKL treatment caused small increases only. Combined treatment with RANKL (10 and $100 \mathrm{ng} / \mathrm{ml}$ ) and low $\mathrm{pH}(\square)$ resulted in dramatic increases in resorption. Values are means with their standard errors represented by vertical bars for five determinations. Significantly different from values for the same RANKL concentration at $\mathrm{pH} 7.4:{ }^{* *} P<0.01,{ }^{* *} P<0.001$. Significantly different from the control values in the same $\mathrm{pH}$ group: $\dagger \dagger P<0.01$.

dietary protein intake in human subjects and rats results in increased urinary $\mathrm{Ca}^{2+}$ and $\mathrm{H}^{+}$excretion (Trilok \& Draper, $1989 a, b)$. Another study with human volunteers has shown that increasing the dietary acid load without altering overall protein intake results in increases in urinary $\mathrm{Ca}^{2+}$ and collagen C-telopeptide excretion, suggesting increased bone resorption (Buclin et al. 2001). However, the influence of dietary protein on acid-base balance in blood is less clear. This area is not well studied, but available data suggest that omnivores may, in fact, have slightly higher blood $\mathrm{pH}$ than age-matched vegetarians with a lower protein intake, despite (or because of) slightly more acidic urine (Ball \& Maughan, 1997). Further investigation into the long-term effects not only of protein, but also alkaliforming fruits and vegetables on acid-base status, bone mass and fracture risk would seem to be warranted (New, 2002; New et al. 2000).

Cola drinks may make a considerable contribution to dietary acid intake in some individuals. $\mathrm{H}_{3} \mathrm{PO}_{4}$ is added to such drinks to yield a $\mathrm{pH}$ of about 2.6; simple titration against $\mathrm{NaOH}$ shows that 1 litre of the common cola drinks contains an acid load equal to about $36 \mathrm{ml} \mathrm{HCl}(1 \mathrm{M})$, corresponding to about $40 \%$ of the fixed $\mathrm{H}^{+}$generated daily by the normal US diet. For comparison, this amount of acid would be neutralised by approximately four $500 \mathrm{mg} \mathrm{CaCO}_{3}$

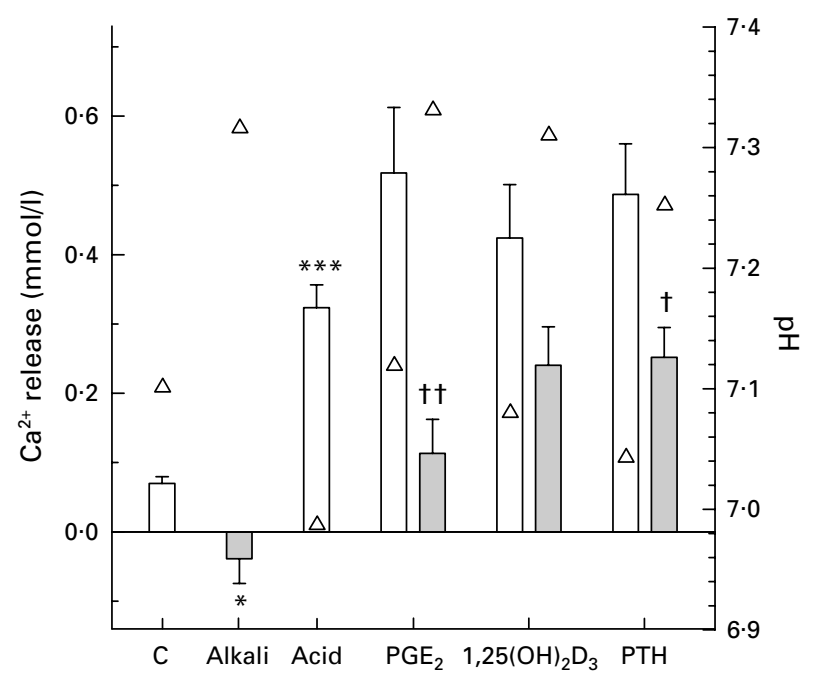

Fig. 8. Dependence of the osteolytic action of prostaglandin $E_{2}$ (PGE $)$, 1,25-dihydroxyvitamin $\mathrm{D}_{3}\left(1,25(\mathrm{OH})_{2} \mathrm{D}_{3}\right)$ and [1-34] bovine parathyroid hormone $(\mathrm{PTH})$ on ambient acidification in $3 \mathrm{~d}$ cultures of mouse half-calvaria. Addition of $15 \mathrm{meq} / \mathrm{l} \mathrm{OH} \mathrm{OH}^{-}$as $\mathrm{NaOH}(\square)$ increased final medium $\mathrm{pH}$ from approximately 7.1 in control cultures $(\square)$ to approximately $7 \cdot 3$, resulting in marked attenuation of $\mathrm{Ca}^{2+}$ release in all treatment groups. Values are means with their standard errors represented by vertical bars for five determinations. Significantly different from the control group (C) values: * $P<0.05$; ${ }^{* \star \star} P<0.001$. Significantly different from respective, non-alkalinized treatment group: $\uparrow P<0.05(\mathrm{PTH})$, †† $P<0.01\left(\mathrm{PGE}_{2}\right)$.

antacid tablets (T. Arnett, unpublished results). However, any deleterious effect of the acid load from $\mathrm{H}_{3} \mathrm{PO}_{4}$ in cola drinks may be offset, at least for bone, because $\mathrm{PO}_{4}{ }^{3-}$ is a powerful reversible inhibitor of the formation and activity of osteoclasts. It is also noteworthy that blood $\mathrm{PO}_{4}{ }^{3-}$, unlike $\mathrm{Ca}^{2+}$ levels, are not tightly regulated and may fluctuate markedly in normal mammals within the range that also regulates osteoclast function (about $2-4 \mathrm{mM}$; Yates et al. 1991).

\section{Ageing and role of vasculature}

With advancing age, there is a slight but notable decrease in blood $\mathrm{pH}$ and $\mathrm{HCO}_{3}{ }^{-}$, i.e. a progressive slight metabolic acidosis. This acidosis, which is probably of dietary origin, is ultimately due to the normal age-related decline in renal function (Frasetto \& Sebastian, 1996; Frassetto et al. 1996). The general quality of the vascular supply around the body also tends to decline with age. In bone, available data indicate that ageing results in a progressive loss of the medullary blood supply, which is only partly compensated by an increase in the periosteal blood supply, leading to marrow ischaemia (Bridgeman \& Brookes, 1996). This trend is also evidenced by the increase in yellow fatty marrow (at the expense of red marrow) with age. The consequence of such ischaemia is hypoxia, which acts as a powerful stimulus for osteoclast formation from marrow precursors (Gibbons et al. 2001), as well as causing a local acidosis, which will favour the resorptive activity of mature 
$\mathrm{pH} 7 \cdot 4$

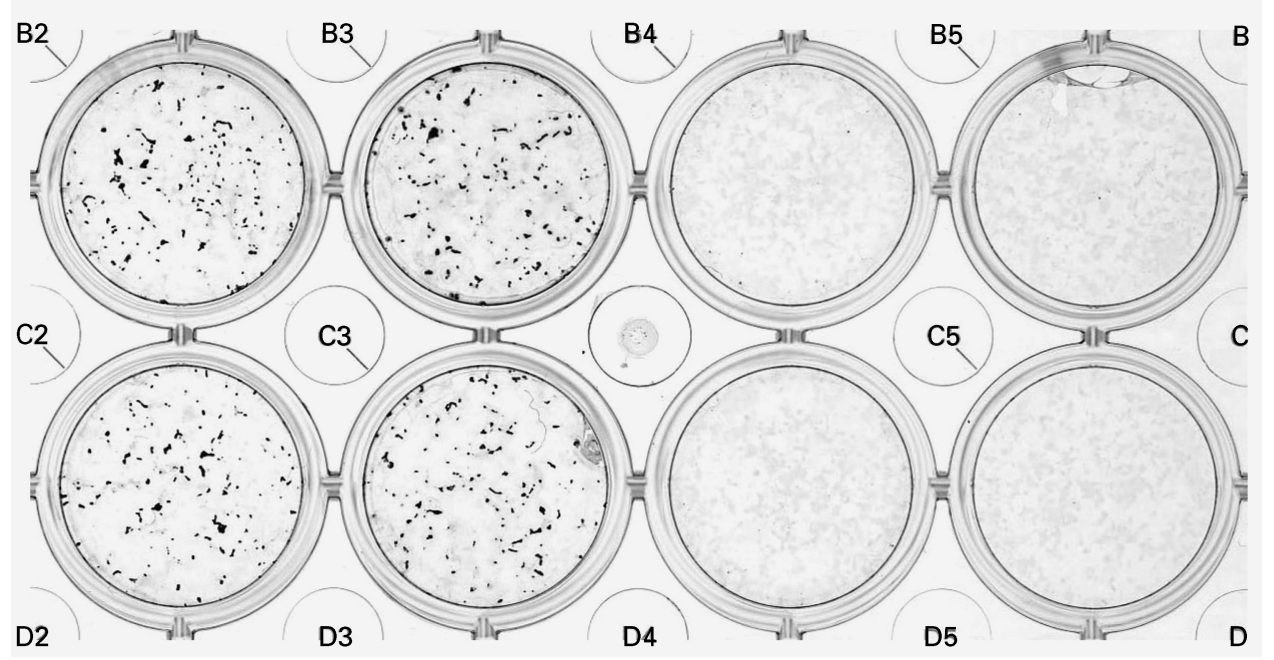

Fig. 9. Inhibition of bone nodule formation by acidosis. Primary rat osteoblasts were cultured in plastic wells for $14 \mathrm{~d}$ in control medium at $\mathrm{pH} 7.4$ or in acidified medium at $\mathrm{pH}$ 6.9. Bony nodules consisting of mineralised extracellular matrix, visualised by alizarin red staining are evident only in control wells. (Reproduced by courtesy of Ms A. Brandao-Burch.)

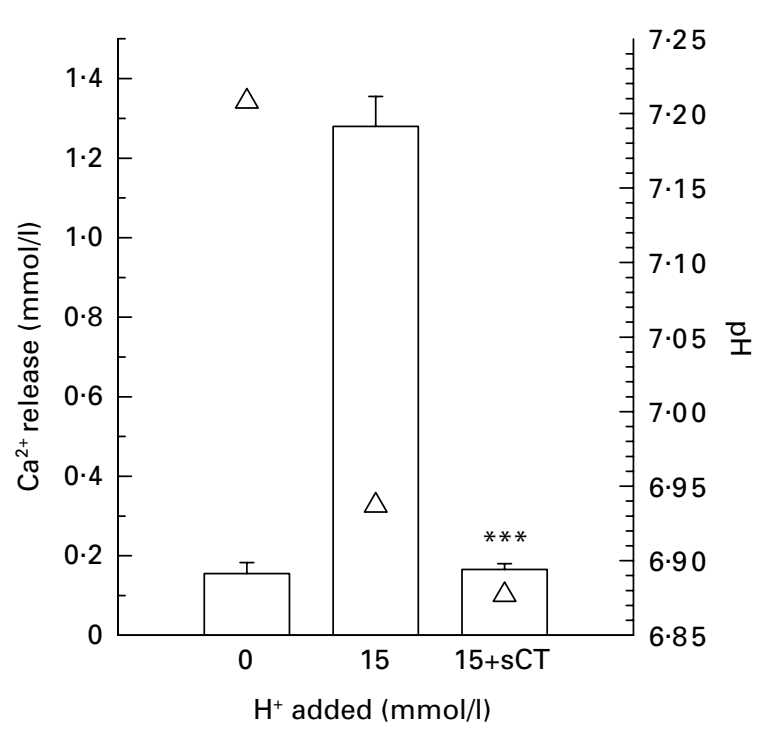

Fig. 10. Complete inhibition of $\mathrm{HCO}_{3}^{-}$acidosis-stimulated $\mathrm{Ca}^{2+}$ release $(\square)$ from $3 \mathrm{~d}$ cultures of mouse half-calvaria by salmon calcitonin (sCT; $20 \mathrm{ng} / \mathrm{ml}) .(\triangle), \mathrm{pH}$. Values are means with their standard errors represented by vertical bars for five determinations. Significantly different from the control values: ${ }^{* \star} P<0.001$.

osteoclasts. Thus, maintenance of a healthy blood supply is likely to be of key importance to skeletal health.

\section{Acid-base balance and anti-osteoporosis therapies}

There is evidence that therapies aimed at limiting osteoporotic bone loss could exert some effects via alterations in systemic acid-base balance. The study of Orr-Walker et al. (1999) reported that hormone-replacement therapy with
(A)

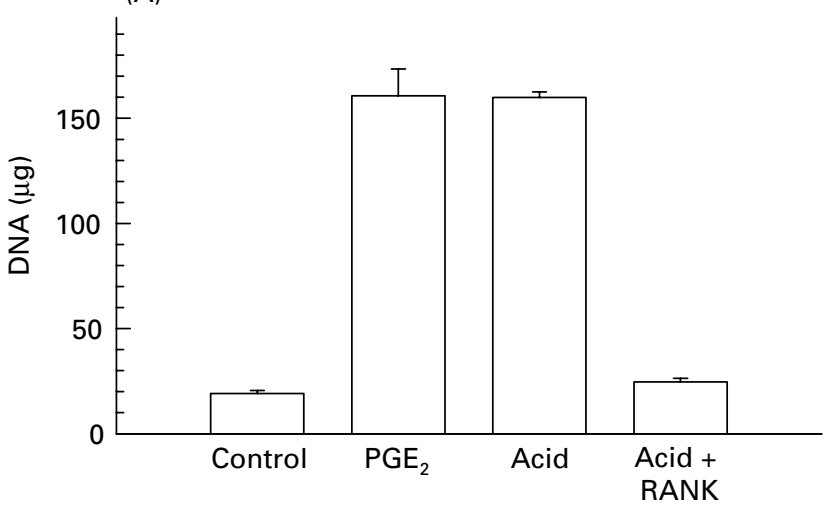

(B)

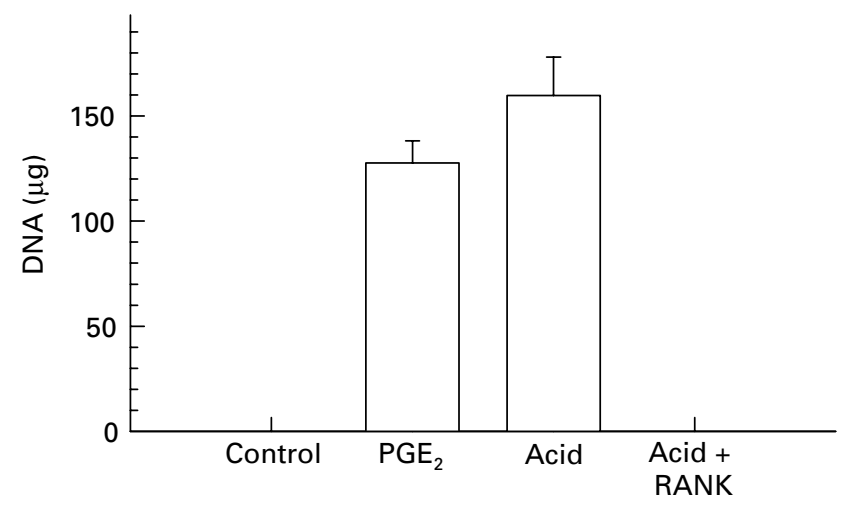

Fig. 11. Semi-quantitative polymerase chain reaction showing up regulation of $m R N A$ for tartrate-resistant acid phosphatase $(A)$ and cathepsin $\mathrm{K}(\mathrm{B})$ in mouse calvarial bones cultured at $\mathrm{pH} 7.05$ (acid) for $3 \mathrm{~d}$. No expression of cathepsin K mRNA was detected in controls or acid + receptor activator of nuclear factor kappa B (RANK) $(\mathrm{pH}$ 7.20). $P \mathrm{PE}_{2}$, prostaglandin $\mathrm{E}_{2}$. Values are means with their standard errors represented by vertical bars for three determinations. (Reproduced by courtesy of Ms A. Brandao-Burch.) 
oestrogen and progestin causes a respiratory alkalosis in normal post-menopausal women, and that changes in blood $\mathrm{pH}$ were inversely correlated with those in urinary excretion of hydroxyproline, an index of bone resorption. The effects appeared to be due to a stimulation of ventilation by progestin. In the rat, testosterone deficiency due to orchiectomy results in mild metabolic acidosis and osteoporosis, which is alleviated by supplementation with alkaline salts (Straub et al. 2001). In post-menopausal women, dietary supplementation with $\mathrm{KHCO}_{3}$ caused marked improvements in mineral balance and indices of resorption, as well as small increases in blood $\mathrm{pH}$ (0.02 units) and $\mathrm{HCO}_{3}{ }^{-}(1.8 \mathrm{mmol} / \mathrm{l}$; Sebastian et al. 1994). The bone-sparing effect of dietary supplementation with alkaline calcium salts is now well established, particularly for elderly women (Dawson-Hughes et al. 1990; Reid et al. 1995). Blood $\mathrm{Ca}^{2+}$ levels, which are tightly regulated in normal subjects, are not substantially altered by ingestion of large quantities of calcium salts. Whether a component of the beneficial action of calcium salts is simply a result of their alkaline nature remains to be determined. However, this idea is certainly consistent with the observations that the anti-osteoporotic effect of $\mathrm{Ca}^{2+}$ supplementation is due to an inhibition of osteoclastic bone resorption (Ginty et al. 1998; Scopacasa et al. 2000), and that alkaline calcium salts are most effective in the individuals who are likely to be acidotic, i.e. the elderly (Frassetto \& Sebastian, 1996; Frassetto et al. 1996).

\section{Conclusion}

Cells are sensitive to external $\mathrm{pH}$ and their function is normally inhibited by acidic conditions. For this reason systemic acid-base balance must be maintained within narrow limits. Osteoclasts, however, are extremely unusual in that their activity is stimulated by, and is dependent on, low $\mathrm{pH}$. This remarkable effect may represent a primitive 'fail-safe' mechanism that evolved with terrestrial vertebrates to correct systemic acidosis by ensuring release of alkaline bone mineral when the lungs and kidneys are unable to remove sufficient $\mathrm{H}^{+}$equivalent. The available evidence suggests that release of bone mineral in response to chronic acidosis is almost entirely an osteoclast-mediated process. Thus, the earlier concept that the skeleton functions as a passive 'ion-exchange column' with regard to acid-base balance must now be revised; the 'last defence' of systemic $\mathrm{pH}$ is perhaps too important to be left to physico-chemical processes. Given the great sensitivity of osteoclasts to ambient $\mathrm{pH}$, it seems likely that even slight chronic acidosis could be sufficient to cause appreciable bone loss over time. Conversely, dietary or hormonal manipulations that result in a small extent of alkalosis might be expected to have a bone-sparing effect.

\section{Acknowledgement}

The author is grateful for the support of the Arthritis Research Campaign and the BBSRC.

\section{References}

Albright F \& Reifenstein EC (1948) The Parathyroid Glands and Metabolic Bone Disease, p. 242. Baltimore, MD: Williams and Wilkins.

Arnett TR \& Dempster DW (1986) Effect of pH on bone resorption by rat osteoclasts in vitro. Endocrinology 119, 119-124.

Arnett TR \& Dempster DW (1987) A comparative study of disaggregated chick and rat osteoclasts in vitro: effects of calcitonin and prostaglandins. Endocrinology 120, 602-608.

Arnett TR \& Dempster DW (1990) Perspectives: protons and osteoclasts. Journal of Bone and Mineral Research 5, 1099-1103.

Arnett TR \& Spowage M (1996) Modulation of the resorptive activity of rat osteoclasts by small changes in extracellular $\mathrm{pH}$ near the physiological range. Bone 18, 277-279.

Avioli LV (1978) Renal osteodystrophy. In Metabolic Bone Disease, vol. II, pp. 149-215 [LV Avioli and SM Krane, editors]. New York: Academic Press.

Ball D \& Maughan RJ (1997) Blood and urine acid-base status of premenopausal omnivorous and vegetarian women. British Journal of Nutrition 78, 683-693.

Barrett MG, Belinsky GS \& Tashiian AH Jr (1997) A new action of parathyroid hormone: receptor-mediated stimulation of extracellular acidification in human osteoblast-like $\mathrm{SaOS}-2$ cells. Journal of Biological Chemistry 272, 26346-26353.

Barzel US (1995) The skeleton as an ion-exchange system implications for the role of acid-base imbalance in the genesis of osteoporosis. Journal of Bone and Mineral Research 10, 1431-1436.

Barzel US \& Jowsey J (1969) The effects of chronic acid and alkali administration on bone turnover in adult rats. Clinical Science 36, 517-524.

Belinsky G \& Tashjian AH Jr (2000) Direct measurement of hormone-induced acidification in intact bone. Journal of Bone and Mineral Research 15, 550-556.

Biskobing DM \& Fan D (2000) Acid pH increases carbonic anhydrase II and calcitonin receptor mRNA expression in mature osteoclasts. Calcified Tissue International 67, 178-183.

Bridgeman G \& Brookes M (1996) Blood supply to the human femoral diaphysis in youth and senescence. Journal of Anatomy 188, 611-621.

Buclin T, Cosma M, Appenzeller M, Jacquet AF, Decosterd LA, Biollaz J \& Burckhardt P (2001) Diet acids and alkalis influence calcium retention in bone. Osteoporosis International 12, 493-499.

Bushinsky DA (1989) Net calcium efflux from live bone during chronic metabolic, but not respiratory, acidosis. American Journal of Physiology 256, F836-F842.

Bushinsky DA (1995) Stimulated osteoclastic and suppressed osteoblastic activity in metabolic but not respiratory acidosis. American Journal of Physiology 268, C80-C88.

Bushinsky DA, Goldring JM \& Coe FL (1985) Cellular contribution to $\mathrm{pH}$-mediated calcium flux in neonatal mouse calvariae. American Journal of Physiology 248, F785-F789.

Bushinsky DA, Krieger NS, Geisser DI, Grossman EB \& Coe FL (1983) Effects of $\mathrm{pH}$ on bone calcium and proton fluxes in vitro. American Journal of Physiology 245, F204-F209.

Bushinsky DA \& Lechleider RJ (1987) Mechanism of protoninduced bone calcium release: calcium carbonate-dissolution. American Journal of Physiology 253, F998-F1005.

Bushinsky DA, Sessler NE \& Krieger NS (1992) Greater unidirectional calcium efflux from bone during metabolic, compared with respiratory, acidosis. American Journal of Physiology 262, F425-F431. 
Chan YL, Savdie E, Mason RS \& Posen S (1985) The effect of metabolic acidosis on vitamin D metabolites and bone histology in uremic rats. Calcified Tissue International 37, 158-164.

Cooke AM (1955a) Osteoporosis. Lancet i, 878-882.

Cooke AM (1955b) Osteoporosis. Lancet i, 929-937.

Cunningham J, Fraher LJ, Clemens TL, Revell PA \& Papapoulos SE (1982) Chronic acidosis with metabolic bone disease. Effect of alkali on bone morphology and vitamin D metabolism. American Journal of Medicine 73, 199-204.

Dawson-Hughes B, Dallal GE, Krall EA, Sadowski L, Sahyoun N \& Tannenbaum S (1990) A controlled trial of the effect of calcium supplementation on bone density in postmenopausal women. New England Journal of Medicine 323, 878-883.

Frassetto LA, Morris RC Jr \& Sebastian A (1996) Effect of age on blood acid-base composition in adult humans: role of age-related renal functional decline. American Journal of Physiology 271, F1114-F1122.

Frassetto L \& Sebastian A (1996) Age and systemic acid-base equilibrium: analysis of published data. Journal of Gerontology 51A, B91-B99.

Frick KK \& Bushinsky DA (1998) Chronic metabolic acidosis reversibly inhibits extracellular matrix gene expression in mouse osteoblasts. American Journal of Physiology 275, F840-F847.

Gibbons DC, Meghji S, Hoebertz A, Rosendaal M \& Arnett TR (2001) Hypoxia is a powerful stimulator of bone resorption. Journal of Bone and Mineral Research 16, 1175.

Ginty F, Flynn A \& Cashman KD (1998) The effect of short-term calcium supplementation on biochemical markers of bone metabolism in healthy young adults. British Journal of Nutrition 80, 437-443.

Goldhaber P \& Rabadjija L (1987) $\mathrm{H}^{+}$stimulation of cell-mediated bone resorption in tissue culture. American Journal of Physiology 253, E90-E98.

Goto K (1918) Mineral metabolism in experimental acidosis. Journal of Biological Chemistry 36, 355-376.

Green J \& Kleeman CR (1991) Role of bone in regulation of systemic acid-base balance. Kidney International 39, 9-26.

Heaney RP (2001) Protein intake and bone health: the influence of belief systems on the conduct of nutritional science. American Journal of Clinical Nutrition 73, 5-6.

Hoebertz A, Meghji S, Burnstock G \& Arnett TR (2001) Extracellular ADP is a powerful osteolytic agent: evidence for signaling through the $\mathrm{P}_{2} \mathrm{Y}_{1}$ receptor on bone cells. FASEB Journal 15, 1139-1148.

Jaffe HL, Bodansky A \& Chandler JP (1932) Ammonium chloride decalcification as modified by calcium intake: the relationship between generalized osteoporosis and ostitis fibrosa. Journal of Experimental Medicine 56, 823-834.

Kraut JA, Mishler DR \& Kurokawa K (1984) Effect of colchicine and calcitonin on calcemic response to metabolic acidosis. Kidney International 25, 608-612.

Lacey DL, Timms E, Tan HL, Kelley MJ, Dunstan CR, Burgess T, Elliott R, Colombero A, Elliott G, Scully S, Hsu H, Sullivan J, Hawkins N, Davy E, Capparelli C, Eli A, Qian YX, Kaufman S, Sarosi I, Shalhoub V, Senaldi G, Guo J, Delaney J \& Boyle WJ (1998) Osteoprotegerin ligand is a cytokine that regulates osteoclast differentiation and activation. Cell 93, 165-176.

Lemann J Jr, Litzow JR \& Lennon EJ (1966) The effects of chronic acid loads in normal man: further evidence for the participation of bone mineral in the defense against chronic metabolic acidosis. Journal of Clinical Investigation 45, 1608-1614.

Martin GR \& Jain RK (1994) Noninvasive measurement of interstitial $\mathrm{pH}$ profiles in normal and neoplastic tissue using fluorescence ratio imaging microscopy. Cancer Research 54, $5670-5674$.

Meghji S, Henderson B, Morrison MS \& Arnett TR (2001) pH dependence of bone resorption: mouse calvarial osteoclasts are activated by acidosis. American Journal of Physiology 280, E112-E119.

Morrison MS \& Arnett TR (1998) pH effects on osteoclast formation and activation. Bone 22, 30S.

Morrison M, Turin L, King BF, Burnstock G \& Arnett TR (1998) ATP is a potent stimulator of the activation and formation of rodent osteoclasts. Journal of Physiology 511, 495-500.

Murrills RJ, Stein LS \& Dempster DW (1993) Stimulation of bone resorption and osteoclast clear zone formation by low $\mathrm{pH}$ : a timecourse study. Journal of Cellular Physiology 154, 511-518.

New SA (2002) The role of the skeleton in acid-base homeostasis. Proceedings of the Nutrition Society 61, 151-164.

New SA, Robins SP, Campbell MK, Martin JC, Garton MJ, Bolton-Smith C, Grubb DA, Lee SJ \& Reid DM (2000) Dietary influences on bone mass and bone metabolism: further evidence of a positive link between fruit and vegetable consumption and bone health? American Journal of Clinical Nutrition 71, 142-151.

Nordström T, Shrode LD, Rotstein OD, Romanek R, Goto T, Heersche JN, Manolson MF, Brisseau GF \& Grinstein S (1997) Chronic extracellular acidosis induces plasmalemmal vacuolar type $\mathrm{H}^{+}$ATPase activity in osteoclasts. Journal of Biological Chemistry 272, 6354-6360.

Orr-Walker BJ, Horne AM, Evans MC, Grey AB, Murray MAF, McNeil AR \& Reid IR (1999) Hormone replacement therapy causes a respiratory alkalosis in normal postmenopausal women. Journal of Clinical Endocrinology and Metabolism 84, 1997-2001.

Rabadjija L, Brown EM, Swartz SL, Chen CJ \& Goldhaber P (1990) $\mathrm{H}^{+}$-stimulated release of prostaglandin $\mathrm{E}_{2}$ and cyclic adenosine $3^{\prime}, 5^{\prime}$-monophosphoric acid and their relationship to bone resorption in neonatal mouse calvaria cultures. Bone and Mineral 11, 295-304.

Reid IR, Ames RW, Evans MC, Gamble GD \& Sharpe SJ (1995) Long-term effects of calcium supplementation on bone loss and fractures in postmenopausal women: a randomized controlled trial. American Journal of Medicine 98, 331-335.

Relman AS (1968) The acidosis of renal disease. American Journal of Medicine 44, 706-713.

Santhanagopal A \& Dixon SJ (1999) Insulin-like growth factor I rapidly enhances acid efflux from osteoblastic cells. American Journal of Physiology 277, E423-E432.

Scopacasa F, Need AG, Horowitz M, Wishart JM, Morris HA \& Nordin BE (2000) Inhibition of bone resorption by divided-dose calcium supplementation in early postmenopausal women. Calcified Tissue International 67, 440-442.

Sebastian A, Harris ST, Ottaway JH, Todd KM \& Morris RC Jr (1994) Improved mineral balance and skeletal metabolism in postmenopausal women treated with potassium bicarbonate. New England Journal of Medicine 330, 1776-1781.

Straub B, Muller M, Schrader M, Heicappell R \& Miller K (2001) Osteoporosis and mild metabolic acidosis in the rat after orchiectomy and their prevention: should prophylactic therapy be administered to patients with androgen deprivation? Journal of Urology 165, 1783-1789.

Trilok G \& Draper HH (1989a) Sources of protein-induced endogenous acid production and excretion by human adults. Calcified Tissue International 44, 335-338.

Trilok G \& Draper HH (1989b) Effect of a high protein intake on acid-base balance in adult rats. Calcified Tissue International 44, 339-342.

Waldmann R, Champigny G, Lingueglia E, De Weille JR, Heurteaux C \& Lazdunski M (1999) $\mathrm{H}^{+}$-gated cation channels. Annals of the New York Academy of Sciences 868, 67-76.

Yates AJ, Oreffo RO, Mayor K \& Mundy GR (1991) Inhibition of bone resorption by inorganic phosphate is mediated by both reduced osteoclast formation and decreased activity of mature osteoclasts. Journal of Bone and Mineral Research 6, 473-478. 